Professional Paper

\title{
ASH FROM THERMAL POWER PLANTS AS SECONDARY RAW MATERIAL*
}

\author{
Vladica ČUDIĆ ${ }^{1}$, Dragica KISIĆ ${ }^{2}$, Dragoslava STOJILJKOVIĆ ${ }^{3}$, and Aleksandar JOVOVIĆ ${ }^{3}$ \\ Institute of Public Health, Belgrade ${ }^{1}$, Economic Society TENT, Obrenovac ${ }^{2}$, University of \\ Belgrade, Faculty of Mechanical Engineering, Belgrade3, Serbia \\ Received in December 2006 \\ Accepted in April 2007
}

\begin{abstract}
The basic characteristic of thermal power plants in the Republic of Serbia is that they use low-grade brown coal (lignite) as a fuel. Depending on the location of coal mines, lignite may have different properties such as heating value, moisture, and mineral content, resulting in different residue upon combustion. Because of several million tonnes of ash and slag generated every year, their granularmetric particle size distribution, and transport and disposal methods, these plants have a negative impact on the environment. According to the waste classification system in the Republic of Serbia, ash and slag from thermal power plants are classified as hazardous waste, but with an option of usability. The proposed revision of waste legislation in Serbia brings a number of simple and modern solutions. A procedure is introduced which allows for end-of-waste criteria to be set, clarifying the point where waste ceases to be waste, and thereby introducing regulatory relief for recycled products or materials that represent low risk for the environment. The new proposal refocuses waste legislation on the environmental impacts of the generation and management of waste, taking into account the life cycle of resources, and develops new waste prevention programmes. Stakeholders, as well as the general public, should have the opportunity to participate in the drawing up of the programmes, and should have access to them.
\end{abstract}

KEY WORDS: arsenic, coal, fouling, secondary raw materials, slagging, waste

Rapid industrialisation has resulted in increased use of natural resources, which has also brought along serious ecological and environmental imbalance due to the dumping of industrial wastes. Sustainable design applies good design practices and good business principles in addition to preserving the natural environment. Environmentally sound management of waste is of major concern in maintaining the quality of the Earth's environment and especially in achieving sound and sustainable development. The First International Conference on Sustainable Construction in 1994 defined sustainable construction as the * This paper has partly been presented at the International short course:
Environmental Management og Industrial Wastes in Western Balkan
Countries within the EC Project "Management and Remediation of Hazardous
Industrial Wastes in the Western Balkan Countries" (INDUWASTE); Zagreb, Croatia, 10-12 October 2006. creation and responsible maintenance of a healthy built environment, based on ecological principles, and by means of an efficient use of resources (1). In keeping with this definition, architects, engineers, owners, contractors and developers have a responsibility to design and select materials and systems that will provide a durable foundation for sustainable communities.

Slagging and fouling (SEF) are one of the main reasons for shutting down thermal power plants due to inefficient heat transfer (2).

The path from fuel to a mature deposit is complex, and includes a great number of variables that influence ash deposition. Characterisation of SEF processes and their assessment through prediction tools thus requires extensive investigation in many related fields. A scheme of this thematic breakdown can be found in Figure 1 (2). 


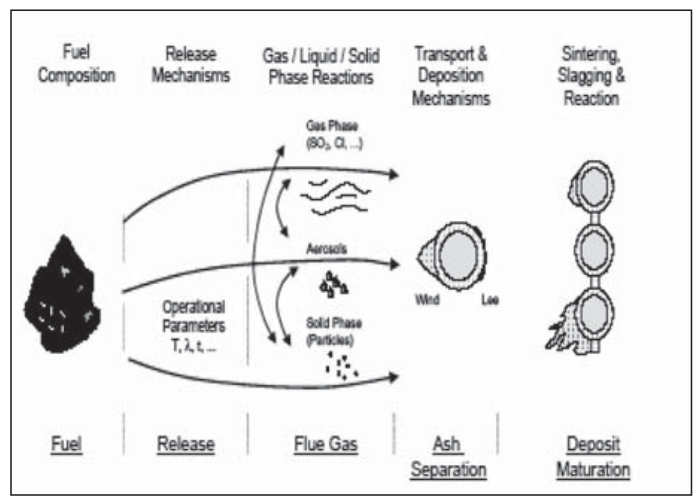

Figure 1 Coal ash formation and deposition

Two types of ash are generated by combustion of fossil fuels: bottom and fly ash. Ash that is collected at the bottom of the boiler is called bottom ash and/or slag. Fly ash is a finer material that is borne by the flue gas from the furnace to the end of the boiler. Bottom ashes are collected and discharged from the boilers, economisers, air heaters, electrostatic precipitators, and fabric filters. Fly ash is collected in economisers and air heaters, or is collected by particulate control equipment. Coal-fired facilities generate the largest quantity of ash. Fly and bottom ash may be managed separately or together in landfills or in wet surface impoundments (3).

Chemical composition of coal ash is a function of the type of coal that is burned. Generally, more than 95 percent of ash is made up of silicon, aluminium, iron, and calcium in their oxide forms, with magnesium, potassium, sodium, and titanium representing the remaining major constituents. Ash may also contain a wide range of trace constituents in highly variable concentrations. Potential trace constituents include antimony, arsenic, barium, cadmium, chromium, lead, mercury, selenium, strontium, zinc, and other metals.

There are several issues related to ash and ash deposition which have been defined as follows:

- Slagging refers to deposition taking place in the boiler sections where radiative heat transfer is dominant.

- Fouling takes place in the cooler convective heat transfer sections of the boiler and results from the behaviour of components as the gases cool down.

- Corrosion takes place when metal from the tube wall reacts with a component from an ash deposit or flue gas.

- Erosion occurs due to the impact of hard particles on tube surfaces and tends to occur in the high velocity sections of the convective part of the boiler, and is exacerbated by partial blockage due to fouling deposits (2).

Products can include extending the life cycle of used materials, contribution to the principle of sustainable development, reducing the contribution to acid rain and global warning typical of coal usage. Materials specify that fly ash may be used in a number of specifications: (a) as a pozzolan in highway pavement concrete, structural concrete, roller compacted concrete and concrete products; (b) as a mineral filler in asphalt roads, embankments and backfills; (c) in soil stabilisation and road base;

Table 1 Heavy and trace metals determined by atomic absorption spectrometry and inductively coupled plasma emission spectrometry in several ash and slag samples

\begin{tabular}{lccccc}
\hline & \multicolumn{5}{c}{ Mass fraction $/ \mathrm{mg} \mathrm{kg}^{-1}$ dry mass } \\
\hline Sample Id. No. & $\begin{array}{c}\text { 11-425/2003 } \\
\text { Thermal power } \\
\text { plant } \\
\text { "MORAVA", } \\
\text { Location }\end{array}$ & $\begin{array}{c}\text { 11-426/2003 } \\
\text { Thermal power } \\
\text { plant } \\
\text { "MORAVA", } \\
\text { Svilajnac 6 }\end{array}$ & $\begin{array}{c}\text { 11-427/2003 } \\
\text { Thermal power } \\
\text { plant } \\
\text { "MORAVA", } \\
\text { Svilajnac 7 }\end{array}$ & $\begin{array}{c}\text { 11- 562/2004 } \\
\text { Thermal power } \\
\text { plant } \\
\text { "NIKOLA } \\
\text { TESLA", } \\
\text { Obrenovac A }\end{array}$ & $\begin{array}{c}\text { 11-102/2006 } \\
\text { Thermal power } \\
\text { plant } \\
\text { "KOLUBARA", } \\
\text { Veliki Crljeni }\end{array}$ \\
\hline Lead (Pb) & $<6$ & 22.8 & 5.3 & $<10$ & 16.9 \\
Cadmium (Cd) & $<1.35$ & $<1.10$ & $<1.10$ & $<2$ & $<3.00$ \\
Zinc (Zn) & 108 & 79.8 & 58.3 & 27 & 67.6 \\
Copper (Cu) & 40.5 & 45.6 & 31.8 & 30 & 76.05 \\
Nickel (Ni) & 87.8 & 74.1 & 53 & 30 & 76.0 \\
Total Chromium (Cr) & 27 & 45.6 & 26.5 & 24 & 62.5 \\
Mercury (Hg) & $<0.15$ & $<0.15$ & $<0.15$ & $<0.10$ & $<0.30$ \\
Arsenic (As) & 31.05 & 59.3 & 30.74 & 73 & 208.55 \\
\hline
\end{tabular}


(d) in stabilised backfills (flowable fills). Bottom ash may be used directly as a lightweight aggregate for cement blocks.

\section{CLASSIFICATION OF ASH AND SLAG FROM THERMAL POWER PLANTS IN SERBIA}

According to the Serbian Law on Waste Handling (4) and Regulations on Conditions and Methods for Classification, Packing and Care of Secondary Raw Materials (5), the Laboratory for Waste Characterisation (Laboratory) within the Institute of Public Health of Belgrade is responsible for identification and classification of waste; national code of waste and other international waste codes for transboundary movement; reporting of transboundary movement and technical guidelines for hazardous waste management. As a competent laboratory for waste characterisation for the Republic of Serbia, the Laboratory is also responsible for identification and characterisation of waste which is generated on its territory, for solid and hazardous waste site evaluation, and hazardous release reporting.

Over the last three years, the Laboratory has been performing chemical analysis of ash and slag from three thermal power plants in Serbia: Obrenovac (6), Svilajnac (7-9) and Veliki Crljeni (10).

According to the results of these analyses, ash and slag from the thermal power plants contain polyaromatic hydrocarbons in the range of $50 \mu \mathrm{g} \mathrm{kg}^{-1}$ to $115 \mu \mathrm{g} \mathrm{kg}^{-1}$ of dry mass [the limit is $100 \mathrm{mg} \mathrm{kg}^{-1}$ of dry mass (11)], polychlorinated dibenzo-p-dioxins (PCDDs) and polychlorinated dibenzofurans (PCDFs) less than $5 \mathrm{ng} \mathrm{kg}^{-1}$ of dry mass [the limit is $15 \mu \mathrm{g}$ $\left.\mathrm{kg}^{-1}(12)\right]$ and total hydrocarbons about $25 \mathrm{mg} \mathrm{kg}^{-1}$ of dry mass [the limit is $20 \mathrm{~g} \mathrm{~kg}^{-1}$ (12)]. Table 1 shows the analysis of trace metals in several samples of ash and slag from thermal power plants in Serbia carried out between 2003 and 2006. Samples were pretreated by digestion with nitric acid $\left(\mathrm{HNO}_{3}\right)$, hydrogen peroxide $\left(\mathrm{H}_{2} \mathrm{O}_{2}\right)$ and hydrochloric acid $(\mathrm{HCl})$, and then analysed using atomic absorption spectrometry and/or inductively coupled plasma emission spectrometry (13). Two samples of ash and slag were analysed using the leaching test according to the European standard EN 12457-2, September 2002 (14). The intent of these tests was to identify the leaching properties of waste. The sample was brought into contact with deionised water and agitated for $(24 \pm 0.5) \mathrm{h}$. The test portion was about $100 \mathrm{~g}(\mathrm{~S})$, and the amount of leachant $(\mathrm{L})$ was set according to the ratio $(\mathrm{L} / \mathrm{S})=10 \mathrm{~L} \mathrm{~kg}^{-1} \pm 2 \%$. After extraction, the eluate was passed through a $0.45 \mu \mathrm{m}$ membrane filter using a pressure filtration device and analysed using atomic absorption spectrometry and/or inductively coupled plasma emission spectrometry. Table 2 shows the analysis of trace metals in the eluate.

The content of arsenic varied in ash and slag. The limit value for total arsenic in waste is $50 \mathrm{mg} \mathrm{kg}^{-1}$ (15). Thermal power plants in Serbia use lignite as a fuel. Depending on the location of coal mines, lignite varies

Table 2 Heavy and trace metals determined by atomic absorption spectrometry and inductively coupled plasma emission spectrometry in the eluate of two ash and slag samples

\begin{tabular}{lcc}
\hline & \multicolumn{2}{c}{ Mass fraction*/ $\mathrm{mg} \mathrm{kg}^{-1}$ dry mass } \\
\hline Sample Id. No. & $\begin{array}{c}11-562 / 2004 \\
\text { Thermal power plant } \\
\text { "NIKOLA TESLA", } \\
\text { Obrenovac A }\end{array}$ & $\begin{array}{c}11-102 / 2006 \\
\text { Thermal power plant } \\
\text { "KOLUBARA", } \\
\text { Veliki Crljeni }\end{array}$ \\
\hline Lead (Pb) & 0.1 & $<0.15$ \\
Cadmium (Cd) & $<0.02$ & $<0.03$ \\
Zinc (Zn) & 0.4 & 0.7 \\
Copper (Cu) & 0.29 & 0.11 \\
Nickel (Ni) & 0.2 & $<0.15$ \\
Total Chromium (Cr) & 0.3 & $<0.15$ \\
Mercury (Hg) & $<0.02$ & $<0.03$ \\
Arsenic (As) & 2.5 & 0.76 \\
\hline
\end{tabular}

*Content in the eluate (neutral leaching test: leachate time: $24 h$, leachate ratio: $L / S=10 / 1$ )

L/S - liquid/solid 
in properties such as heating value, moisture and ash content, which may result in different residue upon combustion.

Several million tonnes of ash and slag generated every year, their granularmetric composition (16), arsenic content, and transport and disposal methods (16) have a considerable negative impact on the environment. According to the waste classification system in Serbia, ash and slag from thermal power plants are classified as hazardous but usable waste, European waste code (EWC) number 100101/190205/190299 (5).

New sampling and ash and slag profiling are planned for all locations, including the study of risks to human health and the environment with a focus on metals, specially arsenic.

\section{ASH AND SLAG FROM THERMAL POWER PLANTS AS A SPECIFIC WASTE STREAM}

Great presence of fossil fuels in everyday life (thermal power plants, heating plants, internal combustion engines, jet and rocket engines, etc.), points to their importance (17). On the other hand, they are the main cause of environmental pollution. This creates an absurd situation in which the use of fossil fuels, whose ultimate goal is better quality of life, leads to a degradation of basic living conditions. Coal-fired utilities represent the largest single category of fossil fuel combustion (FFC), and likewise generate the greatest proportion of FFC wastes. Each year, thermal power plants "Nikola Tesla", TENT A, and TENT B, Obrenovac burn about 22 million tonnes of coal. Utility coal usage results in the generation of about 3.3 million tonnes of large-volume FFC wastes: fly ash, bottom, ash, and boiler slag. These wastes are managed in landfills and surface impoundments, or may be used in a number of ways. Ash and slag landfills are usually lined with compacted clay, asphalt, synthetic, or other type of liners. Significantly, the newer the management unit, the more likely it will possess modern environmental control (liners, monitoring requirements, covers and other features).

In addition to traditional waste management in landfills and surface impoundments, coal combustion waste is used in a variety of applications in Serbia as a secondary raw material. Categories of beneficial use include cement and concrete products, construction fills (including structural and flowable fill, and road base), and its incorporation in other products. The industry trend is to line waste disposal units and use dry ash handling techniques at facilities. Dry ash handling eliminates the use of impoundments for waste management. The available method of collection and hydraulic transport of ash and slag (1:10 ratio of ash and water), has been used at the Thermal Power Plant TENT-B for more than 20 years (18). The above environmental issues are the reason for the reconstruction of the existing system and its replacement with the technology of "thick slurry" (1:1 ratio). Preparation of preliminary design and contracting of equipment are in progress. This will alleviate environmental problems, which will reflect in the following: reduction of water quantities for ash transportation, hence reduction of waste water quantity; elimination of overflows (there will be no discharge of waste - overflow water), and recirculation of drainage water that will reduce the negative effect on the quality of ground waters. In addition, the new technology will enable collecting dry ash and slag in silos and their use in construction.

According to the US EPA (19), wastes generated at coal-fired utilities generally present a low inherent toxicity, are seldom characteristically hazardous, and generally do not present a risk to human health and the environment. Current management practices, trends, and the existing state authorities appear adequate for protection of human health and the environment.

Specific features of ash and slag disposal in Serbia are:

- disposal of large amounts of ash waste disposal sites have a leachate collection system with ground water monitoring;

- frequency control procedures - the frequency of environmental inspection at utilities is among the highest of all the major industry sectors in Serbia. It applies closure control for disposal sites; and

- wide usability.

This is why the future waste legislation will have to give this particular waste stream a special status. It will have to define specific rules for reusable waste and quality standards for materials which contain ash and slag from thermal power plants.

The proposed revision of waste legislation in Serbia brings a number of simple and modern solutions. It will allow for setting end-of-waste criteria, clarifying for the first time the point where waste ceases to be waste, thereby introducing regulatory relief for recycled products or materials that represent low 
risk for the environment. The new proposal refocuses waste legislation on environmental and human health effects related to waste generation and management, taking into account the life cycle of resources, and develops new waste prevention programmes. This new approach in waste legislation will be in accordance with the new European Parliament and Council Directive 2006/12/EC of 5 April 2006 (20).

\section{REFERENCES}

1. Canadian Precast Prestressed Concrete Institute. Introduction [displayed 9 September 2006]. Available at http://www.cpci.ca/?sc= sustainability.

2. López Ch, Unterberger S, Maier J, Hein KRG. Overview of actual methods for characterization of ash depostion. In: Watkinson P, Müller-Steinhagen $\mathrm{H}$, Malayeri MR, editors. Heat Exchanger Fouling and Cleaning: Fundamentals and Applications; 18-22 May 2003; Santa Fe, New Mexico, USA. ECI Engineering Conferences International Symposium Series, Volume RP1 (2003).

3. EPA Sector Notebook - Profile of the Fossil Fuel Electric Power Generation Industry - Part 2. [displayed 9 September 2006]. Available at http://epa.gov/ compliance/resources/publications/assistance/sectors/ notebooks/power2pt2.pdf.

4. Zakon o postupanju sa otpadnim materijama [Law on waste handling, in Serbian] Službeni glasnik RS 1996;(25):798.

5. Pravilnik o uslovima i načinu razvrstavanja, pakovanja i čuvanja sekundarnih sirovina [Regulation regarding conditions and methods of classification, packing and handling of secondary raw materials, in Serbian]. Službeni glasnik RS 2001;(55):7.

6. Institute of Public Health, Belgrade. Test report 2004. Report No. 11-562.

7. Institute of Public Health, Belgrade. Test report 2003. Report No. 11-425.

8. Institute of Public Health, Belgrade. Test report 2003. Report No. 11-426.

9. Institute of Public Health, Belgrade. Test report 2003. Report No. 11-427.

10. Institute of Public Health, Belgrade. Test report 2006. Report No. 11-102.
11. United Nations Environmental Programme (UNEP). Interim guidelines on hazard characteristic $\mathrm{H} 13$ of Annex III to the Basel Convention. Geneva: UNEP. 2004. UNEP/CHW.7/11/Add.3.

12. COUNCIL REGULATION (EC) No 1195/2006 of 18 July 2006 amending Annex IV to Regulation (EC) No 850/2004 of the European Parliament and of the Council on persistent organic pollutants. OJ L 2006;(217):1-3.

13. US Environmental Protection Agency (US EPA). EPA Method 3050b: acid digestion of sediments, sledges and soils. Washington (DC): US EPA; 1997.

14. European Committee for Standardization. Characterization of waste-Leaching - Compliance test for leaching of granular waste materials and sludges - Part 2: One stage batch test at a liquid to solid ratio of $10 \mathrm{~L} / \mathrm{kg}$ for materials with particle size below 4 $\mathrm{mm}$ (without or with size reduction). Bruxelles: CEN; 2002.

15. Committee on Risk-Based Criteria for Non-RCRA Hazardous Waste, National Research Council. RiskBased Waste Classification in California. Washington (DC): National Academy Press; 1999.

16. Kisić $\mathrm{D}$, Bosiljčić R, Vujačić R, Žbogar Z, Boti E. Use of the ash from thermal power plants in the world and in our country. In: Proceedings of the 25th Session of the Yugoslav Committee of the International Conference on Large High Voltage Systems; September 2001; Herceg Novi, Montenegro.

17. Aksentijević S, Đuričić M, Milutinović S. Improvement of environmental protection polluted by fossil fuels. Quality Festival 2006: National Quality Conference: Conference About Quality of Life; 10-12 May 2006, Kragujevac, Srbija. Kragujevac: Kragujevac University; 2006.

18. Simonović B, Gajinov S, Kisić D, Filipović-Rojka Z. Influence of the ash landfill TENT A and TENT B on the ground water. In: Proceedings of the 27th Session of the Yugoslav Committee of the International Conference on Large High Voltage Systems. 29 May - 3 June 2005; Zlatibor, Serbia.

19. US Environmental Protection Agency (US EPA). RCRA Orientation Manuel: Chapter I: Hazardous Waste Identification, [displayed 21 November 2006]. Available at http://www.epa.gov/epaoswer/general/ orientat/rom31.pdf.

20. European Parliament, Council. Directive 2006/12/EC of the European Parliament and of the Council of 5 April 2006 on waste. OJ L 2006;49(114):9. 


\section{Sažetak}

\section{PEPEO IZ TERMOELEKTRANA KAO SEKUINDARNA SIROVINA}

Glavna karakteristika termoelektrana u Srbiji je da upotrebljavaju ugljen - lignit kao gorivo. Zbog velike količine pepela i šljake koji nastaju izgaranjem ugljena (i do nekoliko milijuna tona godišnje), granulometrijskog sastava i izbora metoda transporta i odlaganja, životna sredina izložena je negativnom utjecaju. Prema sistemu klasifikacije otpada u Republici Srbiji pepeo i šljaka iz termoelektrana klasificirani su kao opasan otpad, indeksnog broja iz Kataloga otpada 100101/190205/190299 s upotrebnom vrijednošću. Pepeo i šljaka generirani na lokaciji termoelektrana "Nikola Tesla", Obrenovac i "Kolubara", Veliki Crljeni sadržavaju arsen u koncentracijama od $70 \mathrm{mg} \mathrm{kg}^{-1}$ do $200 \mathrm{mg} \mathrm{kg}^{-1}$ suhe mase.

U duhu reciklaže, a s aspekta smanjenja upotrebe prirodnih resursa, moguće je postaviti nove kriterije za specifične vrste otpada, kao što je pepeo iz termoelektrana. Potrebno je uvesti postupak za određivanje kriterija kada otpad prestaje da bude otpad, uvesti zakonske olakšice za reciklirane otpade i razviti nove programe za prevenciju nastajanja otpada. U budućim zakonskim propisima iz područja upravljanja otpadima potrebno je uzeti u obzir životni ciklus proizvoda i materijala, od njihova nastanka do konačnog odlaganja.

KLJUČNE RIJEČI: arsen, klasifikacija otpada, otpad, izgaranje, ugljen

Vladica Čudić, B.Sc.

Institute of Public Health

Bulevar despota Stefana 54a, 11000 Belgrade, Serbia

E-mail: labwaste@yubc.net 